\title{
Vigilance Behaviour of Wild Herbivores When Foraging With Or Without Livestock
}

\author{
Angelamercy Baltazary ${ }^{1,2}$, Eivin Røskaft ${ }^{3} \&$ Anna C. Treydte ${ }^{1,4}$ \\ ${ }^{1}$ School of Life Science, The Nelson Mandela African Institution of Science and Technology, P.O Box. 447, \\ Tengeru, Arusha, Tanzania \\ 2 Tanzania Wildlife Management Authority, P.O.Box 2658 Morogoro, Tanzania \\ ${ }^{3}$ Department of Biology, Norwegian University of Science and Technology, Realfagbygget, No-7491, \\ Trondheim, Norway \\ ${ }^{4}$ Agroecology in the Tropics and Subtropics, Hans Ruthenberg Institute, University of Hohenheim, Stuttgart, \\ Germany \\ Correspondence: Angelamercy Baltazary, School of Life Science, The Nelson Mandela African Institution of \\ Science and Technology, P.O Box. 447, Tengeru, Arusha, Tanzania. Tel: 255-752-410-816. E-mail: \\ angelamercyb@yahoo.com, baltazarya@nm-aist.ac.tz
}

Received: February 8, 2019

Accepted: February 22, $2019 \quad$ Online Published: February 28, 2019

doi:10.5539/enrr.v9n1p64

URL: https://doi.org/10.5539/enrr.v9n1p64

\begin{abstract}
In African savannas and many other rangelands around the world, wildlife presently find themselves interacting with livestock. Many studies have been conducted on vigilance behaviour in response to presence of predators but few scientists have included the presence of livestock and how this affects vigilance when foraging together with wild herbivores. As the Ngorongoro Conservation Area (NCA) is an important example for wildlife grazing together with livestock this phenomenon must be understood to achieve a sustainable land use management plan. Behavioral observations of wildlife and livestock species were conducted from a vehicle driving along transects within NCA. Four wild herbivore species including plains Zebra (Equus burchelli), Thomson's gazelle (Gazella thomsonii), Grant's gazelle (Gazella granti) and Wildebeest (Connochaetes taurinus). We assessed behavior classified as feeding, grooming, laying down, ruminating, grooming, moving, and looking with head up (vigilance) with the use of the focal animal sampling method. Wild herbivores were observed either with or without livestock species, i.e., cattle (Bos taurus), goats (Capra aegagrus hircus) and sheep (Ovis aries), over two different seasons. Out of 158 groups in total, 47/49 non -mixed groups (without livestock) and 30/32 mixed groups (with livestock) were recorded during the dry/wet season, respectively. Results shows that wildlife decreased their foraging time while they increased vigilance behavior when livestock were present in unprotected land with presence of herder unlike in protected land. Therefore, we conclude that the presence of livestock does not seem to be beneficial for wild herbivores and that protected areas where pastoralists cannot access are important.
\end{abstract}

Key words: Livestock-wildlife interaction, Ngorongoro Conservation Area, rangelands, pastoralists

\section{Introduction}

Rangelands across the world have been a home to millions of people with their livestock interacting with wildlife over the last centuries (Tyrrell, Russell, \& Western, 2017). Today, more than $90 \%$ of the mammal biomass on the earth consists of people with their livestock, and this proportion is still increasing (Thornton, 2010; Bar-on, Phillips, \& Milo, 2018). Rangelands have created a complex set of conservation challenges globally and, for example in African savannas, wild herbivores strongly interact with livestock on a daily basis (Ogutu, Piepho, \& Said, 2011; Riginos et al., 2012; Lind et al., 2013; Veblen et al., 2016). The presence of livestock in rangelands can negatively affect native wild ungulate foraging due to competition (Ruckstuhl, 2006). Furthermore, overlap it the use of forage can lead to behavioural changes in wildlife by altering their activity budgets (Kie, 1995; Ruckstuhl, 2006). Also, wild herbivores have often been regarded as competitors to livestock by altering the behavior and productivity of the latter (Zimmermann et al., 2009; Atickem, et al, 2010; Riginos et al., 2012).

Many studies have been conducted on the vigilance behaviour that is in response to the presence of predators on foraging grounds. However, while most studies investigated foraging competition between wild and domestic 
herbivores (Atickem \& Loe, 2013;; Patton, Dong, Nyren, \& Nyren, 2007 ;Leeuw et al., 2001;Odadi, Okeyo-owuor, $\&$ Young, n.d), only few scientists have investigated how the presence of livestock affects vigilance when foraging together with wild herbivores.

As Ngorongoro Conservation Area is a multiple land use where wild and livestock grazing together, this phenomenon must be understood to achieve a sustainable land use management plan in the long run in Ngorongoro Conservation Area as well as in other protected areas. This study investigated whether wild herbivores change their behavioural activities (grazing, vigilance) when livestock and herders are present on their foraging grounds and whether this behaviour changes with season and location. We expected that wildlife would benefit from foraging in association with livestock in terms of time devoted to feeding. We assessed whether wildlife was more or less vigilant when grazing together with or in the vicinity of livestock through behavioural scan observations

\section{Methods}

\subsection{Study Area}

This study was conducted in the Ngorongoro Conservation Area (NCA) in northern Tanzania $\left(3^{\circ} 14^{\prime} 29.56^{\prime \prime} \mathrm{S}\right.$ and $35^{\circ} 29^{\prime} 16^{\prime \prime E}$ (Figure 1). Ngorongoro Conservation Area was selected for this study due to the fact that it is a multiple land use area for wildlife, people and their livestock and a UNESCO World Heritage Site (Melita, 2014). The presence of pastoralists in NCA, who have coexisted with wildlife in this area for more than 200 years has led to year-long interactions between humans, wildlife and livestock (Homewood \& Rodgers, 1991).

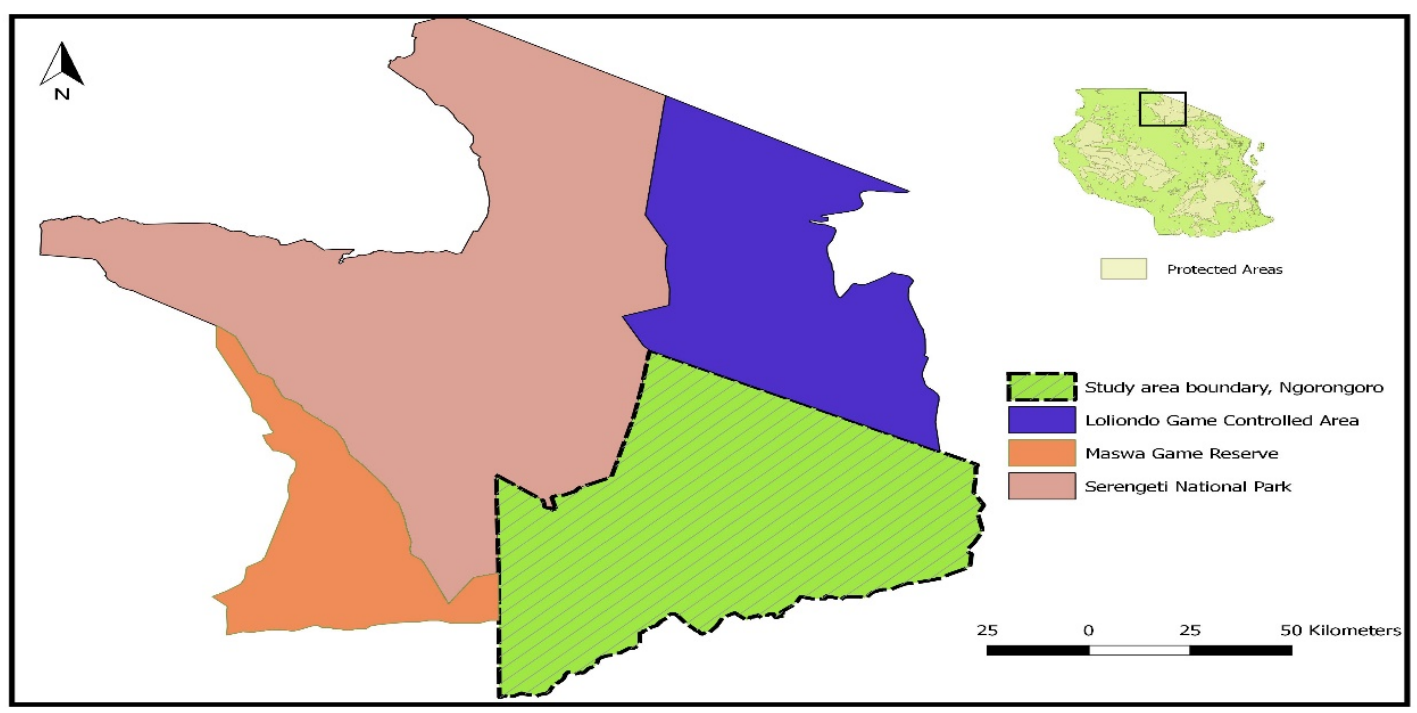

Figure 1. Study area map

The main economic activities in the Ngorongoro Conservation Area are livestock keeping and tourism (Melita, 2014). The livestock species include cattle (Bos taurus), goat (Capra aegagrus hircus), sheep (Ovis aries) and donkeys (Equus asinus). Dominant wildlife species present in NCA include plains Zebra (Equus burchelli), Eland (Tragelaphus oryx), Wildebeest (Connochaetes taurinus) African buffalo (Syncerus caffer), Oryx (Oryx gazelle), Grant's gazelle (Gazella granti), Thomson's gazelle (Gazella thomsonii), as well as megaherbivores such as giraffe (Giraffa camelopardalis) and African elephant (Loxodonta africana) (Odadi, 2012) All of these species have been observed to sometimes associate with livestock in Kenyan rangelands (Odadi, 2012). This world's largest volcanic caldera (Ngorongoro Crater) is $260 \mathrm{~km}^{2}$ large, with an altitude range between 1,700 masl and 2,235 masl, between the crater floor and the rim, respectively (Gaidzik, 2011). The climatic zones vary from semi-arid to montane forests, and annual precipitation ranges from $500 \mathrm{~mm}$ to $1700 \mathrm{~mm}$, which leads to temperature fluctuations between $2^{\circ} \mathrm{C}$ and $35^{\circ} \mathrm{C}$ (Masao, Makoba, \& Sosovele, 2015). Average annual temperatures vary between $14^{\circ} \mathrm{C}$ to $25^{\circ} \mathrm{C}$, the crater floor part has higher temperatures compared to the rim (Masao et al., 2015). Also the presence of grassland and water (lakes and rivers) used by wild herbivores has made the area very latent. 


\subsection{Behavioral Observations}

Behavioral observations of wild and domestic mammalian herbivore species were conducted from a vehicle driving along existing roads at $10 \mathrm{~km} / \mathrm{h}$ (Tyrrell et al., 2017) within NCA. Once a wildlife group (i.e., more than five animals) was sighted the vehicle was stopped and sighting information was recorded. The distances from the observer to a group ranged from $50 \mathrm{~m}$ to $100 \mathrm{~m}$, according to recommendations by Kluever et al., (2008); Robinette $\& \mathrm{Ha},(2001)$. However, in the Ngorongoro crater, i.e., the core protection zone with wildlife species only, these distances was less than $50 \mathrm{~m}$. After 3 minutes of habituation we recorded species and number of animals in the group, and whether livestock was associated with the wild animals. Groups were recorded between May to August 2018 , i.e., the end of the wet until the middle of the dry season to cover potential differences in behavior across seasons. During direct observations, binoculars and camera-recordings were used as well as a stop watch. Distance was recorded using a laser rangefinder (Leica) and coordinates taken by a hand held GPS (eTrex). In order to avoid pseudo-replication we avoided recording similar groups in the vicinity of the first recorded group (Buckland, 2001). Behavior was classified as (1) foraging, (2) grooming, (3) resting, (4) ruminating, (5) grooming, (6) moving, (7) looking with head up (vigilance) (Hariohay, Jackson, Fyumagwa, \& Røskaft, 2018). However, in the further analyses, we tested only vigilance and foraging behavior. The focal animal sampling method was used (Altmann, 2014). Four dominant wild herbivore species that were frequently seen together with livestock in Kenya (Odadi, 2011) were selected for observations, i.e., plains Zebra, Thomson's gazelle, Grant's gazelle and wildebeest, while the livestock species included cattle, goats and sheep. Only adult individuals were observed and females with calves and juveniles were avoided because they might be more vigilant by default (Shorrocks \& Cokayne, 2005). Also, cars and people that passed the vehicle on the road during the observation were recorded as they might have influenced behaviour. Factors that might have affected vigilance were determined livestock presence (at a nearest neighbor distance of $100 \mathrm{~m}$ from the randomly selected focal animal) (Kluever et al., 2008) and presence of female / male herder. An animal was considered vigilant when the head was raised above the shoulder level and it appeared to be looking around (Shorrocks \& Cokayne, 2005; Pe'riquet et al., 2010). Observations were taken over a minimum of a 30-minutes per group, during which the focal animal's behavior within a group was recorded every 1 minute (Kluever et al., 2008). The observation periods fell between 08:00 and 18:00 hours over two months during the wet season and two months during the dry season.

\subsection{Statistical Analyses}

We performed statistical data analyses using R Package 3.5.5. We generated Wilcox tests to test difference in mean foraging time and vigilance time between groups with or without livestock during wet and dry seasons, as well as inside and outside the crater. Also multivariate analyses were performed in order to test the relationship between variables including the presence of herders and groups with livestock in different season. Statistical significance was set at $\mathrm{P}<0.05$

\section{Results}

Out of 158 groups recorded 47 non -mixed groups (without livestock) and 30 mixed groups (with livestock) were observed in the dry season, while, during wet season 49 non -mixed groups and 32 mixed groups were observed. Average group size was 41 individuals during the wet and 24 during the wet season. The numbers of focal wild herbivores recorded in groups without livestock during wet season were 112 while during dry season 81 focal wild herbivores were recorded. Wild herbivores recorded in groups with livestock during wet season were 42 focal wild herbivores, while during dry season were 37 focal wild herbivores. Therefore, the total number of focal wild herbivores observed during both seasons in groups with or without livestock were 272 .

\subsubsection{Mean Foraging Time}

The foraging time compared was on the wild herbivores outside crater associated with livestock and wild herbivores inside crater without livestock. Outside crater there were few mono-specific wildlife groups, that is why were not included in statistical analysis Generaly, the mean foraging time was significantly higher within the crater, that was about twice as high than that outside the crater during wet seasons $(\mathrm{W}=1887.5, \mathrm{n}=112, \mathrm{P}<$ 0.001 ; Figure 2 ) while it was only by $1 / 4$ higher in the crater than outside during dry season $(\mathrm{W}=1050.5, \mathrm{n}=81$, $\mathrm{P}=0.01144$, Figure 2). 


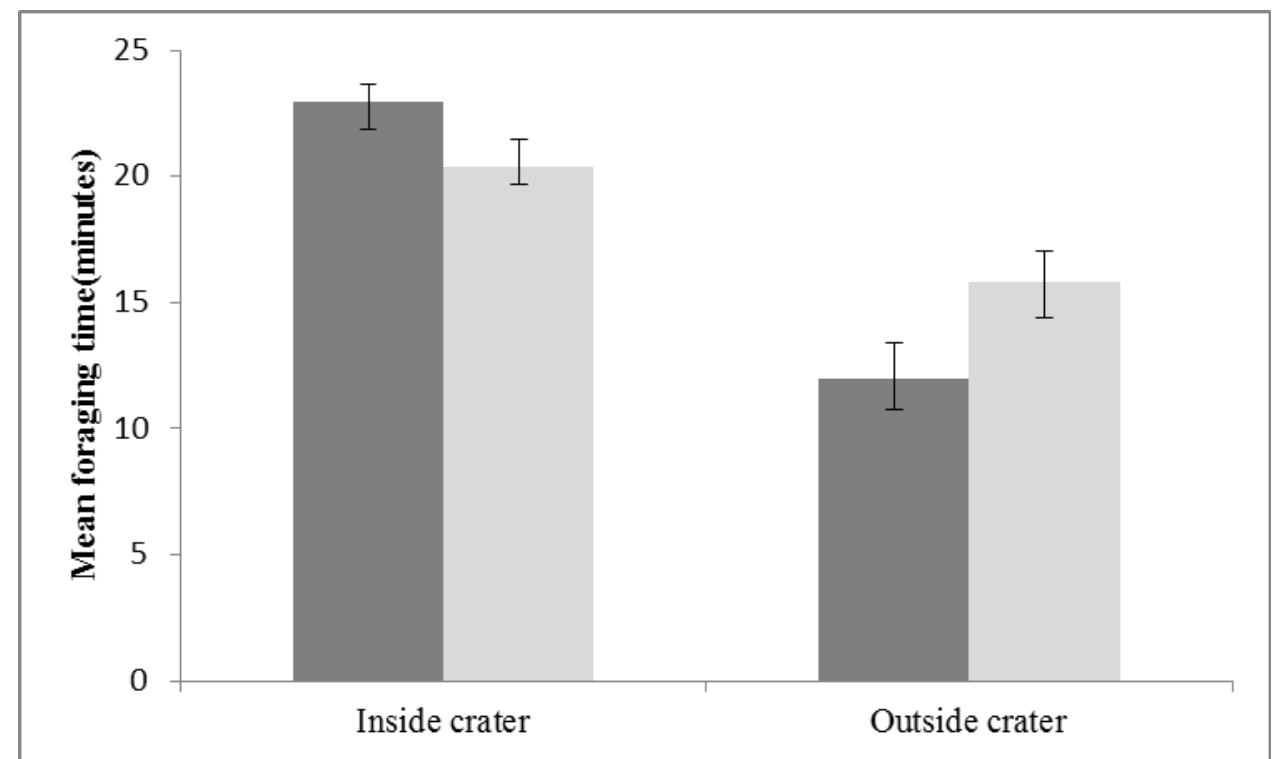

Figure 2. Mean $( \pm \mathrm{SE})$ foraging time outside and inside the crater, i.e., in mixed herds with livestock and herds without livestock, respectively, during dry (grey bar) and wet (black bar) season

\subsubsection{Mean Vigilance Time}

Generaly, the mean vigilance time was significantly higher outside the crater, that was about twice as high than that within the crater during wet seasons $(\mathrm{W}=347.5, \mathrm{n}=112, \mathrm{P}<0.001$; Figure 3 ) while it was only by $1 / 4$ higher in the crater than outside during dry season $(\mathrm{W}=355.5, \mathrm{n}=84, \mathrm{P} 0,001$, Figure. 3 ).

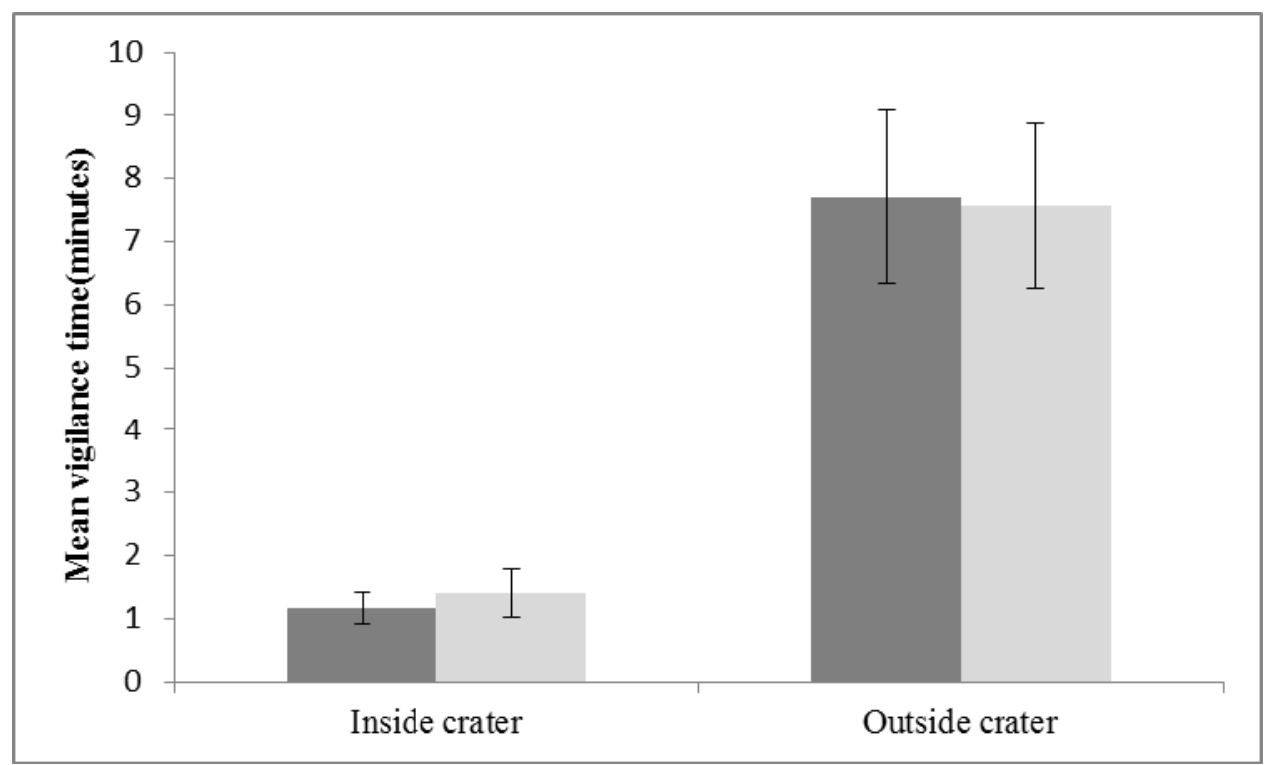

Figure 3. Mean $( \pm$ SE) vigilance time outside and inside the crater, i.e., in mixed herds with livestock and herds without livestock, respectively, during dry (grey bar) and wet (black bar) season 


\subsection{Foraging Time in Groups with or without Livestock Across Seasons}

\subsubsection{Wildebeest}

Foraging time of Wildebeest was significantly higher in groups without livestock than in groups with livestock species during both the wet and dry season, respectively $(\mathrm{W}=56.5, \mathrm{n}=42, \mathrm{P}=0.0097$; and $\mathrm{W}=7.5, \mathrm{n}=23, \mathrm{P}=$ 0.0409 (Figure.4).

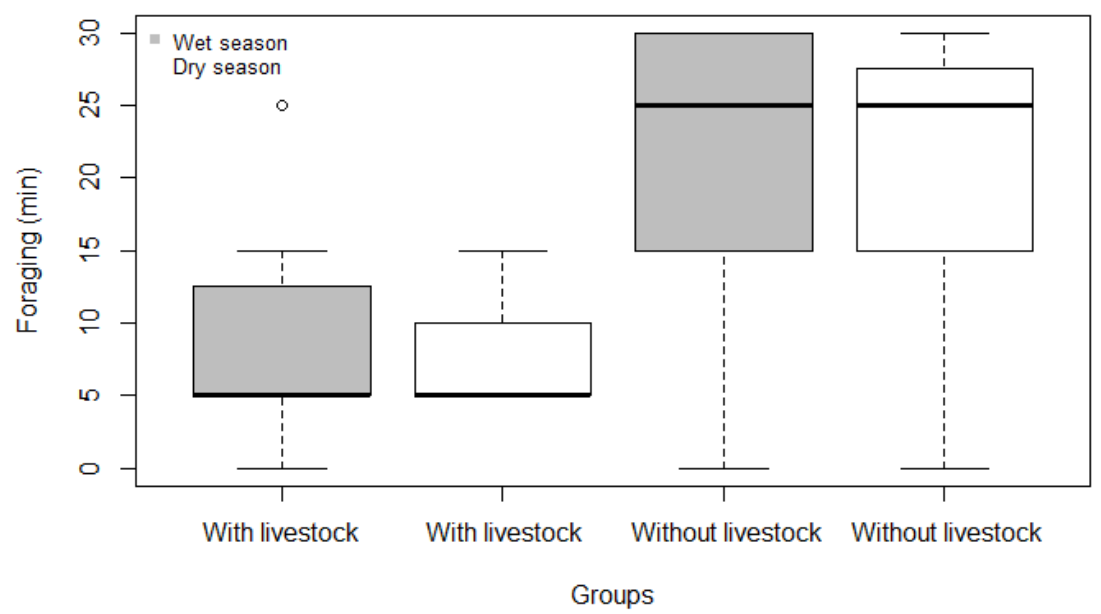

Figure 4. Foraging time of Wildebeest with or without livestock during wet and dry seasons

\subsubsection{Zebra}

Foraging time of Zebra was significantly higher in groups without livestock than in groups including livestock species, during the wet season ( $\mathrm{W}=58.5, \mathrm{n}=35, \mathrm{P}=0.00823$ ) while foraging time of Zebra did not differ significantly between groups with or without livestock during dry season $(\mathrm{W}=332, \mathrm{n}=53, \mathrm{P}=0.593$ (Figure 5)

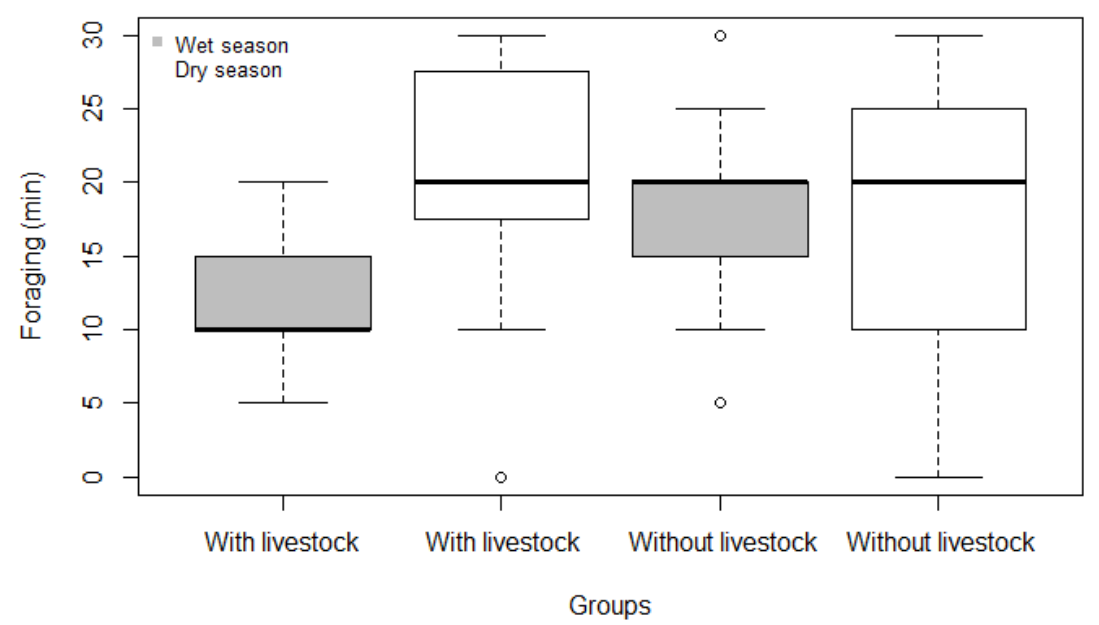

Figure 5. Foraging time of Zebra with or without livestock during wet and dry seasons

\subsubsection{Grant Gazelle}

Foraging time of Grant Gazelle during wet and dry season was non significantly higher in groups without than in groups including livestock species. $(\mathrm{W}=82, n=32, \mathrm{P}=0.149$; and $\mathrm{W} 41.5, n=18, \mathrm{P}=0.387$, respectively (Figure6). 


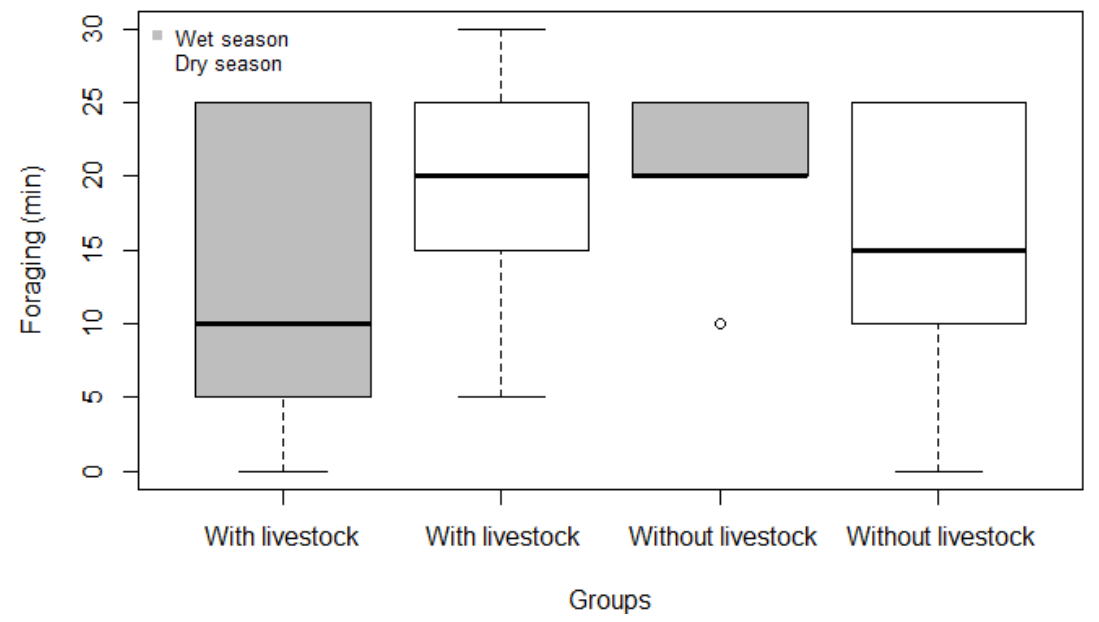

Figure 6. Foraging time of Grant Gazelle with or without livestock during wet and dry season

\subsubsection{Thomson's Gazelle}

Foraging time of Thomson's gazelle during wet season was significantly higher in groups without livestock than in group including livestock species $(\mathrm{W}=121, \mathrm{n}=45, \mathrm{P}=0.024)$ while during the dry season foraging time did not different between the two kind of groups $(\mathrm{W}=45, \mathrm{n}=24, \mathrm{P}=0.7101$, Figure 7 ).

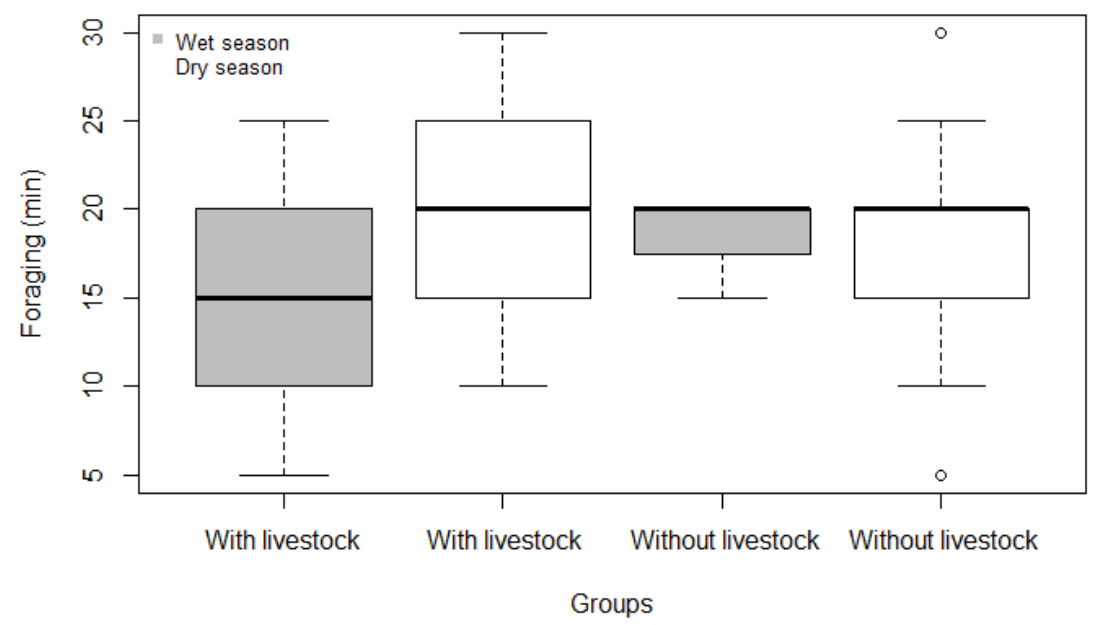

Figure 7. Foraging time of Thomson's gazelle with or without livestock during wet and dry season

\subsection{Vigilance Time in Groups with or without Livestock Across Seasons}

\subsubsection{Wildebeest}

Vigilance time of wildebeest was significantly higher in mixed group including livestock species than in nonmixed group during wet season ( $\mathrm{W}=236, \mathrm{n}=38, \mathrm{P}=<0.001$ ), while vigilance time of Wildebeest was not significantly different between non- mixed group and mixed group during dry season $(\mathrm{W}=33, \mathrm{n}=23, \mathrm{P}=0.7515$, Figure 8).

\subsubsection{Zebra}

Vigilance time of Zebra was significantly higher in mixed group (with livestock) than in non- mixed group (without livestock) during wet season ( $\mathrm{W}=214.5, n=35, \mathrm{P}=0.00155)$, while vigilance time of Zebra was not significantly different between non- mixed (without livestock) group and mixed group (with livestock) during dry season. ( $\mathrm{W}=417.5, n=53, \mathrm{P}=0.3182$, Figure 9). 


\subsubsection{Grant Gazelle}

Vigilance time of Grant Gazelle was not significantly different in mixed including livestock species and non-mixed group during wet season $(\mathrm{W}=110, \mathrm{n}=32, \mathrm{P}=0.6422)$ while vigilance time of Grant Gazelle during dry season was higher in mixed group than non-mixed group. However, the different was not significantly different $(\mathrm{W}=41.5, n=18, \mathrm{P}=0.3873$, Figure 10).

\subsubsection{Thomson's Gazelle}

Vigilance time of Thomson's gazelle was significantly higher in non-mixed group than mixed group during wet and dry season. However, the different was not significant $(\mathrm{W}=198, \mathrm{n}=45, \mathrm{P}=0.7918$; and $\mathrm{W}=23.5, \mathrm{n}=24$, $\mathrm{P}=0.182$ respectively (Figure 11 ).

\subsection{Protection Status Determining Foraging and Vigilant Time}

We used a linear regression analysis to analyze the foraging and vigilant time of four wildlife species (Zebra, Wildebeest, Grant Gazelle and Thomson's gazelle) in relation to protection status. Vigilance and foraging time as dependent variables and then included protection status i.e presence of herder males and herder females as independent variables, group type (with or without livestock) and season.

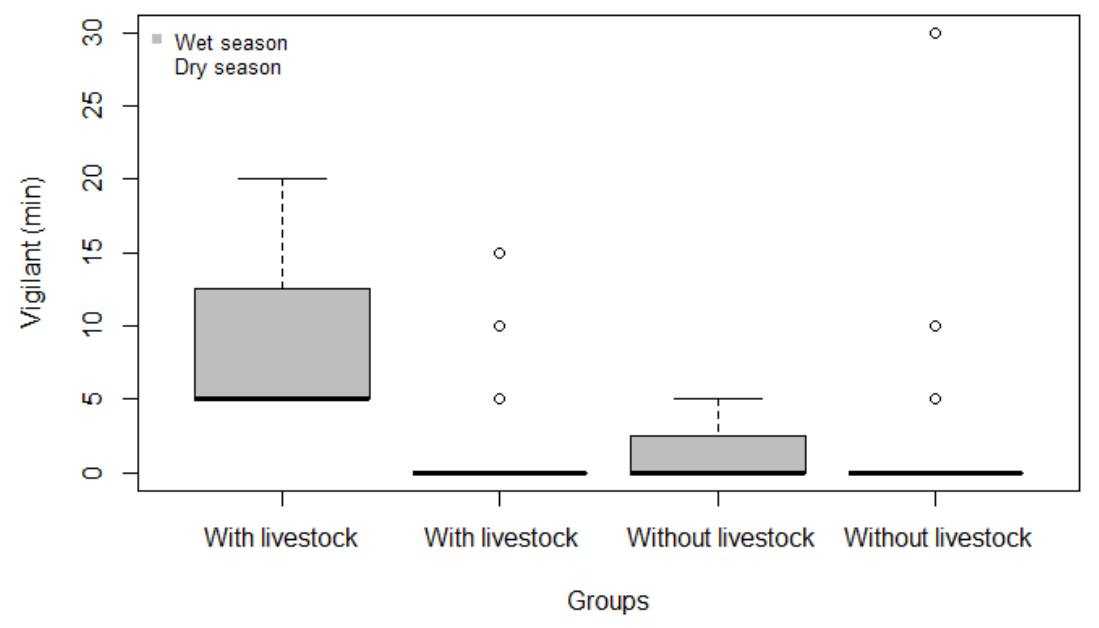

Figure 8. Vigilant time of Wildebeest with or without livestock during wet and dry season

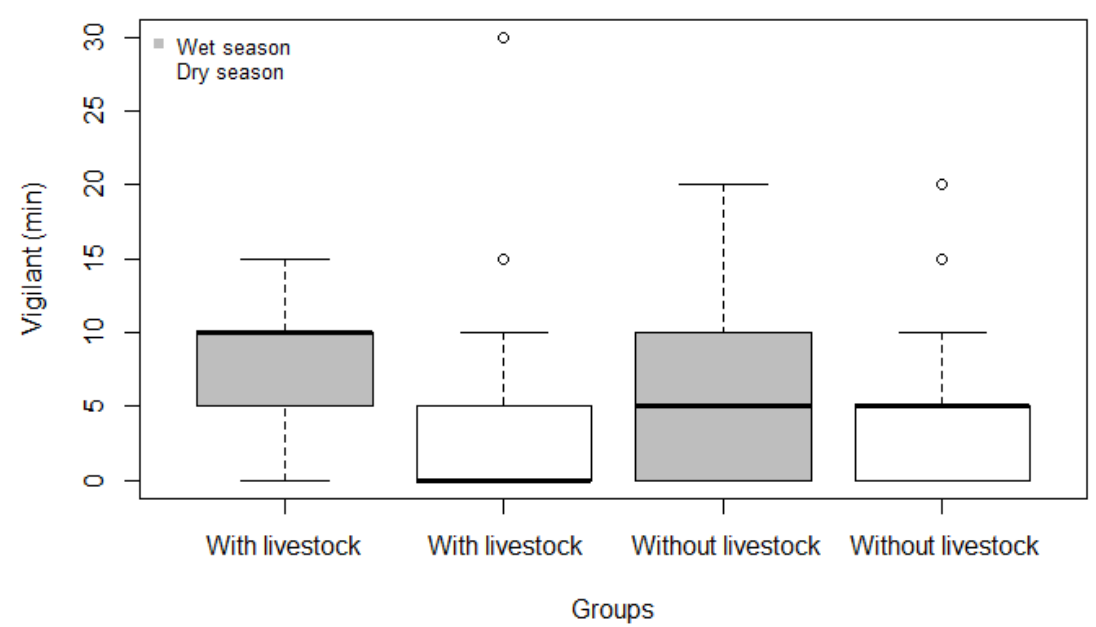

Figure 9. Vigilant time of Zebra with or without livestock during wet and dry season 


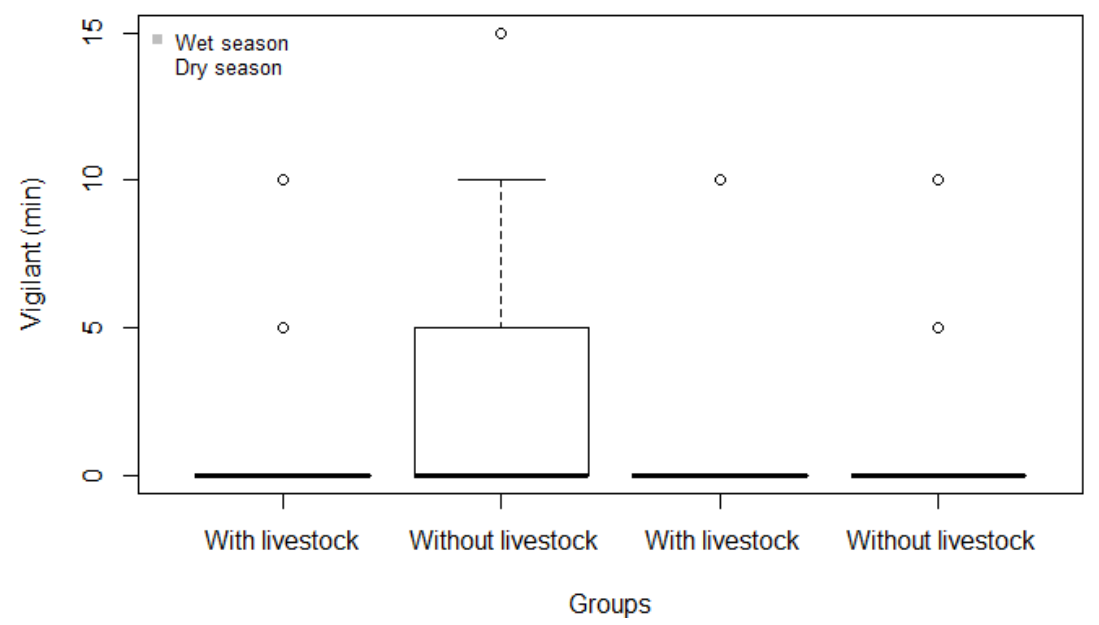

Figure 10. Vigilant time of Grant Gazelle with or without livestock during wet and dry season

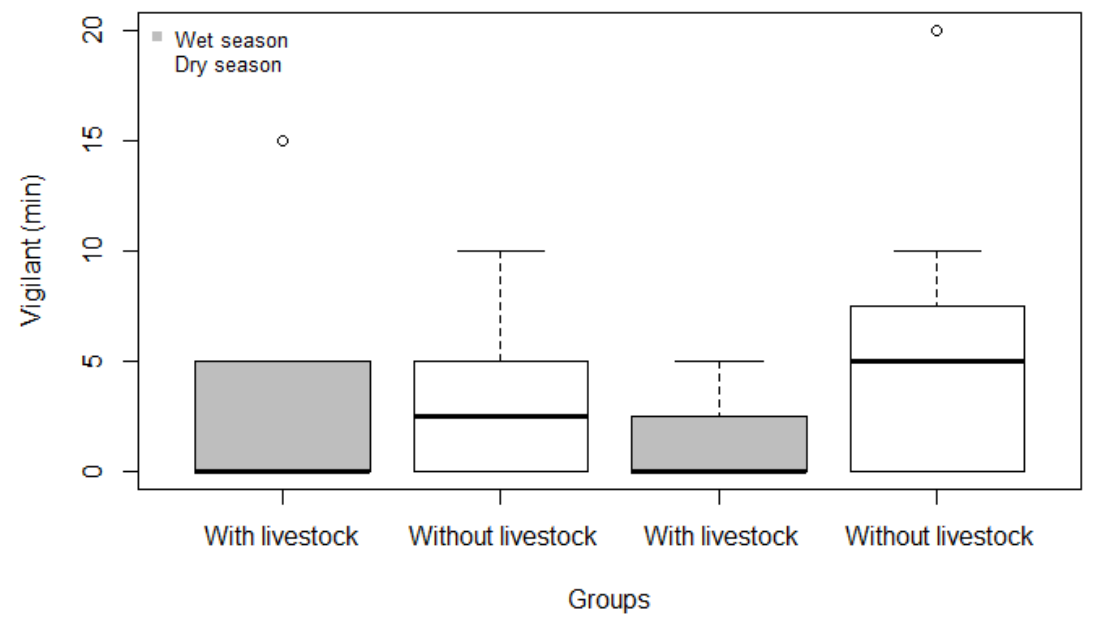

Figure 11. Vigilance time of Thomson's gazelle with or without livestock

\subsubsection{Herder Presence and Vigilance}

For wildebeest, neither the presence of male herders $(t=-0.085, P=0.9323)$ nor that of female herders $(t=$ $-0.108, \mathrm{P}=0.9146)$ significantly influenced foraging time. The presence of livestock significantly reduced foraging time during the dry $(\mathrm{t}=-2.126, \mathrm{P}=0.0376)$ but not during the wet season $(\mathrm{t}=-1.496, \mathrm{P}=0.1398)$ (Table $1)$. The presence of male herders also increased vigilance time significantly $(t=2.194, P=0.03208)$ while the presence of female herders did not $(\mathrm{t}=0.906 \mathrm{P}=0.36844)$ (Table 2)

For Zebra, the presence of herder males $(t=1.100 \mathrm{P}=0.27432)$ or herder females $(t=0.486, \mathrm{P}=0.62820)$ did not significantly contribute in explaining the variation in foraging time, however presence of livestock during wet season $(t=-2.761, P=0.00708)$ did significantly contribute in explaining the foraging time of Zebra. On the other hand, during dry season the presence of livestock $(t=-0.979, P=0.33026)$ did not add any significance in explaining the foraging time of Zebra (Table 3). Also the presence of herder males $(\mathrm{t}=-1.335, \mathrm{P}=0.18548)$ or herder females $(\mathrm{t}=-1.483, \mathrm{P}=0.14184)$ did not significantly contribute to explain the vigilance time of Zebra, while the presence of livestock in both seasons $(\mathrm{t}=2.648, \mathrm{P}=0.00966)$ and $(\mathrm{t}=2.185, \mathrm{P}=0.03168)$ were significantly contributors to explain the variation in Zebra's vigilance time (Table 4). 
Table 1. Relationship between Wildebeest foraging time and protection status during wet and dry season

\begin{tabular}{lrrrl}
\hline & Estimate & Std. Error & $\mathrm{t}$ value & $\operatorname{Pr}(>|\mathrm{t}|)$ \\
\hline (Intercept) & 20.5556 & 1.3189 & 15.585 & $<2 \mathrm{e}-16^{* * *}$ \\
Male herder & -0.1464 & 1.7169 & -0.085 & 0.9323 \\
Female herder & -0.7741 & 7.1891 & -0.108 & 0.9146 \\
With livestock wet & -11.0576 & 7.3893 & -1.496 & 0.1398 \\
With livestock dry & -12.2222 & 5.7490 & -2.126 & $0.0376^{*}$ \\
\hline
\end{tabular}

Table 2. Relationship between Wildebeest vigilant time and protection status during wet and dry season

\begin{tabular}{lrrrl}
\hline & Estimate & Std. Error & $\mathrm{t}$ value & $\operatorname{Pr}(>|\mathrm{t}|)$ \\
\hline (Intercept) & 2.2222 & 0.7030 & 3.161 & $0.00247^{* *}$ \\
Male herder & 2.0084 & 0.9152 & 2.194 & $0.03208^{*}$ \\
Female herder & 3.4728 & 3.8322 & 0.906 & 0.36844 \\
With livestock wet & -1.0507 & 3.9389 & -0.267 & 0.79058 \\
With livestock dry & -0.5556 & 3.0645 & -0.181 & 0.85675 \\
\hline
\end{tabular}

Table 3. Relationship between Zebra foraging time and protection status during wet and dry season

\begin{tabular}{lrrrl}
\hline & Estimate & Std. Error & $\mathrm{t}$ value & $\operatorname{Pr}(>|\mathrm{t}|)$ \\
\hline (Intercept) & 18.9623 & 1.0957 & 17.307 & $<2 \mathrm{e}-16^{* * *}$ \\
Male herder & 0.8080 & 0.7343 & 1.100 & 0.27432 \\
Female herder & 0.5775 & 1.1881 & 0.486 & 0.36844 \\
With livestock wet & -8.7781 & 3.1796 & -2.761 & $0.00708^{* *}$ \\
With livestock dry & -2.1167 & 2.1615 & -0.979 & 0.33026 \\
\hline
\end{tabular}

Table 4. Relationship between Zebra vigilant time and protection status during wet and dry season

\begin{tabular}{lrrrl}
\hline & Estimate & Std. Error & $\mathrm{t}$ value & $\operatorname{Pr}(>|\mathrm{t}|)$ \\
\hline (Intercept) & 3.9623 & 0.8221 & 4.820 & $6.31 \mathrm{e}-06^{* * *}$ \\
Male herder & -0.7355 & 0.5510 & -1.335 & 0.18548 \\
Female herder & -1.3219 & 0.8914 & -1.483 & 0.14184 \\
With livestock wet & 6.3176 & 2.3857 & 2.648 & $0.00966^{* *}$ \\
With livestock dry & 3.5434 & 1.6218 & 2.185 & $0.03168^{*}$ \\
\hline
\end{tabular}

For Grant Gazelle, the presence of herder males $(\mathrm{t}=0.982, \mathrm{P}=0.331)$ did not significantly contribute in explaining the variation in foraging time while the presence of herder females $(\mathrm{t}=-2.022, \mathrm{P}=0.049)$ contributed significantly in explaining this variation in the foraging time. Further, the presence of livestock during wet and dry season $(\mathrm{t}=-1.444, \mathrm{P}=0.155)$ and $(\mathrm{t}=-0.097, \mathrm{P}=0.923)$ respectively, did not significantly contribute in explaining the variation in foraging time of Grant Gazelle (Table 5). Also the presence of herder males $(\mathrm{t}=1.346, \mathrm{P}=$ $0.18491)$ and herder females $(t=-1.025, P=0.31052)$ did not significantly contribute in explaining the variation in the vigilance time of Grant Gazelle, as well as the presence of livestock in both seasons $(t=1.260, P=0.21385)$ and $(t=0.242, P=0.80969)$ did not contribute significantly in the explanation of variation in Grant Gazelle's vigilance time (Table 6)

Table 5. Relationship between Grant Gazelle foraging time and protection status during wet and dry season

\begin{tabular}{lllll}
\hline & Estimate & Std. Error & $\mathrm{t}$ value & $\operatorname{Pr}(>|\mathrm{t}|)$ \\
\hline (Intercept) & 17.7027 & 1.2741 & 13.894 & $<2 \mathrm{e}-16^{* * *}$ \\
Male herder & 1.4669 & 1.4946 & 0.982 & 0.331 \\
Female female & -19.0083 & 9.3997 & -2.022 & $0.049^{*}$ \\
With livestock wet & -7.4961 & 5.1902 & -1.444 & 0.155 \\
With livestock dry & -0.4196 & 4.3442 & -0.097 & 0.923 \\
\hline
\end{tabular}


Table 6. Relationship between Grant Gazelle vigilant time and protection status during wet and dry season

\begin{tabular}{lllll}
\hline & Estimate & Std. Error & $\mathrm{t}$ value & $\operatorname{Pr}(>|\mathrm{t}|)$ \\
\hline (Intercept) & 2.0270 & 0.6281 & 3.227 & $0.00231^{* *}$ \\
Male herder & 0.9917 & 0.7368 & 1.346 & 0.18491 \\
Female herder & -4.7521 & 4.6341 & -1.025 & 0.31052 \\
With livestock wet & -3.2254 & 2.5588 & -1.260 & 0.21385 \\
With livestock dry & -0.5188 & 2.1417 & -0.242 & 0.80969 \\
\hline
\end{tabular}

For Thomson's gazelle the presence of herder males $(t=-0.293, P=0.770)$ or herder females $(t=0.972, P=$ 0.335 ) did not significantly contribute in explaining the variation in foraging time. Further, the presence of livestock during wet and dry season $(\mathrm{t}=1.460, \mathrm{P}=0.149)$ and $(\mathrm{t}=-0.185, \mathrm{P}=0.854)$ respectively, did not significantly contribute in explain the variation in foraging time of Thomson's Gazelle (Table 7). Also the presence of herder males $(t=0.210, P=0.834)$ or herder females $(t=0.099, P=0.922)$ did not significantly contribute in explaining the variation in the vigilance time of Thomson's gazelle, as well as the presence of livestock in both seasons $(\mathrm{t}=-0.501, \mathrm{P}=0.618)$ and $(\mathrm{t}=-0.826, \mathrm{P}=0.412)$ (Table 8$)$

Table 7. Relationship between Thomson 's gazelle foraging time and protection status during wet and dry season

\begin{tabular}{lllll}
\hline (Intercept) & 19.5192 & 0.8498 & 22.970 & $<2 \mathrm{e}-16 * * *$ \\
\hline Male herder & -0.2724 & 0.9298 & -0.293 & 0.770 \\
Female herder & 3.9332 & 4.0481 & 0.972 & 0.335 \\
With livestock wet & -4.3926 & 3.0084 & 1.460 & 0.149 \\
With livestock dry & -0.7318 & 3.9547 & -0.185 & 0.854 \\
\hline
\end{tabular}

Table 8. Relationship between Thomson's Gazelle vigilant time and protection status during wet and dry season

\begin{tabular}{lllll}
\hline & Estimate & Std. Error & $\mathrm{t}$ value & $\operatorname{Pr}(>|\mathrm{t}|)$ \\
\hline (Intercept) & 3.7500 & 0.6018 & 6.232 & $4.27 \mathrm{e}-08 * * *$ \\
Male herder & 0.1381 & 0.6584 & 0.210 & 0.834 \\
Female herder & 0.2827 & 2.8667 & 0.099 & 0.922 \\
With livestock wet & -1.0677 & 2.1304 & -0.501 & 0.618 \\
With livestock dry & -2.3136 & 2.8005 & -0.826 & 0.412 \\
\hline
\end{tabular}

\section{Discussion}

\subsection{Foraging Times with or without Livestock}

In our study, both during the wet and dry season the proportional foraging time devoted by wild herbivores increased when the wild mammalian herbivores foraged without livestock. This may have been influenced the presence of protective herders (Young, Palmer, \& Gadd, 2005), which we also found in our study. However, we found that foraging behavior also differed between species, across the areas of different protection and across season as supported by the study conducted by Dunham, (1982).

\subsection{Vigilance between Species in Groups with or without Livestock in Different Season}

From our study the vigilance time devoted by wild herbivores in both seasons decreased in groups without livestock but increased in groups associated with livestock. This was contracting to the study conducted by Kluever, et al, (2008); Pe'riquet, et al, (2010) and Mclaren, (2014) who showed that herbivores associated with other species (wildlife) gained a vigilance advantage, that mixed-species herds provided a relatively unexplored opportunity to tease apart the effects of dilution, whereby individual herding with other species displayed lower frequency of vigilance than when herding only. In mixed groups of livestock and wild herbivores, as well groups without livestock, the behaviors of individuals were different in Ngorongoro rangelands, where wild herbivores spent more time on foraging in group without livestock than when associate with livestock in Ngorongoro rangelands. Wildlife also spent more time foraging within the crater than outside the crater (in village land and along crater rim) even though when not associated with livestock. This is because there is abundant forage within the crater. Also, the presence of these different factors might influence whether wild herbivores are vigilant 
rather than concentrating on foraging (Fritz et al. 2002; Crosymary et al, 2002). The results revealed that all four wild herbivores were more vigilant in both seasons when associated with livestock, although it was not significant in all cases.

\subsection{Foraging and Vigilance Behavior of Wild Herbivore in Crater in Different Season}

In the crater wild herbivores spent more time foraging because they were not associated with livestock. Previously, (before 2016) Maasai were allowed to graze their livestock in the crater but since 2016 they are not allowed to graze and lick salt in that area. Hence the increase in proportional time of wild herbivores of foraging was due to lack of disturbance from livestock. Despite the fact that in crater there were many tourists and cars wild herbivores were still very comfortable (Personal observation, 2018) and the proportional time of vigilance and other activities were minimized, as instead they increased the proportional time of foraging. Therefore, our study provide these information as Ngorongoro Conservation Area Authority (NCAA) and other policy makers may use them during preparation of land use planning in other conservation areas.

\subsection{Protection Status Determining Foraging and Vigilant Time}

The result revealed that the level of protection has an influence on vigilant time of wildlife species that, the group which was herded by males, Wildebeest was more vigilant than the group which was herded by females. This was contradicting to the study by Young et al., (2005) that wildlife do keep their distance from individuals herded by protective herders. In NCA wildlife do not keep distance from them but the result shows that Wildebeest increase the time of vigilance while other species did not do this may be due to the fact that Wildebeest mostly associate with cattle and they were herded by males. However, Zebra increased vigilance when associated with livestock in both seasons. Thomson's gazelle and Grant Gazelle did not increase the vigilance time which may be due the fact that Thomson's gazelle and Grant Gazelle were mostly associated with shoats which were mostly herded by females. Therefore, this justifies that the protection status may determine the level of vigilance time and that male herders are more protective compared to females.

\section{Conclusion}

Our study illustrates how livestock behaviourally influence wild herbivores especially with regard to foraging and vigilance behavior. In case of NCA, the multiple land use makes it difficult to separate Maasai from conservation, Maasai may continue to utilize other areas for their livestock use but leave out the Crater for the use of wild herbivores only. This is because inside the crater wild herbivores have more time to forage instead of being vigilant. This may lead to the increase of the population of wild herbivores inside the crater (Arsenault, R., \& Owen-smith, 2010) and maintain the status of NCA as a source area, while outside the crater the area might serve as Zink.

\section{Acknowledgments}

We are thankful to the World Bank through CREATES for funding Master studies and write up of this research. Furthermore, we extend our gratitude to Rufford foundation and Idea Wild for additional funds. Also we would like to thank Ngorongoro Conservation Area Authority and the Tanzania Wildlife Research Institute (TAWIRI) for granting us the access to conduct this research study. We would also like to extend our thanks to Juma Mkwizu (driver) and Jacob Yudah for assistance in the field.

\section{Reference}

Altmann, J. (1974). Observational study of behavior: sampling methods. Behaviour, 49(3-4), 227-266.

Arsenault, R., \& Owen-Smith, N. (2002). Facilitation versus competition in grazing herbivore assemblages. Oikos, 97(3), 313-318.

Atickem, A., Williams, S., Bekele, A., \& Thirgood, S. (2010). Livestock predation in the Bale Mountains, Ethiopia. African Journal of Ecology, 48(4), 1076-1082.

Bar-On, Y. M., Phillips, R., \& Milo, R. (2018). The biomass distribution on Earth. Proceedings of the National Academy of Sciences, 115(25), 6506-6511. https://doi.org/10.1073/pnas.1711842115

Chaikina, N. A., \& Ruckstuhl, K. E. (2006). The effect of cattle grazing on native ungulates: the good, the bad, and the ugly. Rangelands, 28(3), 8-15.

Dunham, K. M. (1982). The foraging behaviour of impala Aepy ceros melampus. South African Journal of Wildlife Research-24-month delayed open access, 12(1), 36-40. 
Hariohay, K. M., Jackson, C. R., Fyumagwa, R. D., \& Røskaft, E. Trophy Hunting Versus Ecotourism as a Conservation Model? Assessing the Impacts on Ungulate Behaviour and Demographics in the Ruaha-Rungwa Ecosystem, Central Tanzania. https://doi.org/10.5539/enrr.v8n2p33

Kie, J. G. (1999). Optimal foraging and risk of predation: effects on behavior and social structure in ungulates. Journal of Mammalogy, 80(4), 1114-1129.

Kluever, B. M., Breck, S. W., Howery, L. D., Krausman, P. R., \& Bergman, D. L. (2008). Vigilance in cattle: the influence of predation, social interactions, and environmental factors. Rangeland Ecology \& Management, 61(3), 321-328.

Leeuw, J. De, Waweru, M. N., Okello, O. O., Maloba, M., Nguru, P., Said, M. Y., ... Reid, R. S. (2001). Distribution and diversity of wildlife in northern Kenya in relation to livestock and permanent water points,

Lind, E. M., Borer, E., Seabloom, E., Adler, P., Bakker, J. D., Blumenthal, D. M., ... \& Stanley Harpole, W. (2013). Life-history constraints in grassland plant species: a growth-defence trade-off is the norm. Ecology letters, 16(4), 513-521. https://doi.org/10.1111/ele.12078.Rights

Masao, C. A., Makoba, R., \& Sosovele, H. (2015). Will Ngorongoro Conservation Area remain a world heritage site amidst increasing human footprint?. International Journal of Biodiversity and Conservation, 7(9), 394-407. https://doi.org/10.5897/IJBC2015.0837

Mclaren, B. E. (2014). Concepts \& Synthesis, (February 2012). https://doi.org/10.2307/23143908

Melita, A. W., \& Authority, N. C. A. (2014). The Relationship between Tourism and Socio-Economic Aspects of the Maasai in Ngorongoro Conservation, Tanzania. Business and Management Horizons, 2(1), 78-97. https://doi.org/10.5296/bmh.v2i1.5860

Odadi, W. O., Karachi, M. K., Abdulrazak, S. A., \& Young, T. P. (2011). African wild ungulates compete with or facilitate cattle depending on season. science, 333(6050), 1753-1755. https://doi.org/10.1126/science. 1208468

Ogutu, J. O., Owen-Smith, N., Piepho, H. P., \& Said, M. Y. (2011). Continuing wildlife population declines and range contraction in the Mara region of Kenya during 1977-2009. Journal of Zoology, 285(2), 99-109. https://doi.org/10.1111/j.1469-7998.2011.00818.x

Périquet, S., Valeix, M., Loveridge, A. J., Madzikanda, H., Macdonald, D. W., \& Fritz, H. (2010). Individual vigilance of African herbivores while drinking: the role of immediate predation risk and context. Animal Behaviour, 79(3), 665-671. https://doi.org/10.1016/j.anbehav.2009.12.016

Patton, B. D., Dong, X., Nyren, P. E., \& Nyren, A. (2007). Effects of Grazing Intensity , Precipitation , and Temperature on Forage Production. Rangeland Ecology Management, 60(6), 656-665. https://doi.org/10.2111/07-008R2.1

Riginos, C., Porensky, L. M., Veblen, K. E., Odadi, W. O., Sensenig, R. L., Kimuyu, D., ... \& Young, T. P. (2012). Lessons on the relationship between livestock husbandry and biodiversity from the Kenya Long-term Exclosure Experiment (KLEE). Pastoralism: Research, Policy and Practice, 2(1), 10.

Robinette, R. L., \& Ha, J. C. (2001). Social and ecological factors influencing vigilance by northwestern crows, Corvus caurinus. Animal Behaviour, 62(3), 447-452. https://doi.org/10.1006/anbe.2001.1772

Shorrocks, B., \& Cokayne, A. (2005). Vigilance and group size in impala (Aepyceros melampus Lichtenstein): a study in Nairobi National Park, Kenya. African Journal of Ecology, 43(2), 91-96.

Thornton, P. K. (2010). Livestock production: recent trends, future prospects. Philosophical Transactions of the Royal Society B: Biological Sciences, 365(1554), 2853-2867. https://doi.org/10.1098/rstb.2010.0134

Tyrrell, P., Russell, S., \& Western, D. (2017). Seasonal movements of wildlife and livestock in a heterogenous pastoral landscape: implications for coexistence and community based conservation. Global Ecology and Conservation, 12, 59-72. https://doi.org/10.1016/j.gecco.2017.08.006

Underwood, R. (1982). Vigilance behaviour in grazing African antelopes. Behaviour, 79(2-4), 81-107.

Veblen, K. E., Porensky, L. M., Riginos, C., \& Young, T. P. (2016). Are cattle surrogate wildlife? Savanna plant community composition explained by total herbivory more than herbivore type. Ecological Applications, 26(6), 1610-1623. https://doi.org/10.1890/15-1367.1 
Young, T. P., Palmer, T. M., \& Gadd, M. E. (2005). Competition and compensation among cattle, zebras, and elephants in a semi-arid savanna in Laikipia, Kenya. Biological conservation, 122(2), 351-359. https://doi.org/10.1016/j.biocon.2004.08.007

Żaba, J., \& Gaidzik, K. (2011). The Ngorongoro Crater as the biggest geotouristic attraction of the Gregory Rift ( Northern Tanzania , Africa ) - geographical setting. Geoturystyka, 2, 3-26.

Zimmermann, A., Baker, N., Inskip, C., Linnell, J. D., Marchini, S., Odden, J., ... \& Treves, A. (2010). Contemporary views of human-carnivore conflicts on wild rangelands. Wild rangelands: Conserving wildlife while maintaining livestock in semi-arid ecosystems, 129-151.

\section{Copyrights}

Copyright for this article is retained by the author(s), with first publication rights granted to the journal.

This is an open-access article distributed under the terms and conditions of the Creative Commons Attribution license (http://creativecommons.org/licenses/by/4.0/). 